\title{
A New Record Mayfly Ephemerella subvaria McDunnough (Ephemeroptera, Ephemerellidae) from Ohio, USA
}

\author{
DONALD H. DEAN', Departments of Entomology, and Chemistry and Biochemistry, The Ohio State University, Columbus, \\ $\mathrm{OH}$, USA; and BRIAN FLECHSIG, Mad River Outfitters, Columbus, OH, USA.
}

\begin{abstract}
In the spring of 2019, a new state record for a mayfly (Ephemeroptera) was collected at Cedar Run and the Mad River in Champaign County, Ohio, United States. Ephemerella subvaria McDunnough, 1931, was collected and identified as nymphs and subsequently reared to adults. This Ohio location is exceptional. The geographic distribution of the species is widespread in the eastern United States; however, its distribution in the upper midwest is limited to northern Michigan and northern Wisconsin, but is absent from the southern counties of those states, and from Illinois. It is rare in Indiana and northern Kentucky. Until this report it was unknown from Ohio. Nymphs were collected on 26 March 2019. Reared in a temperature-controlled aquarium, the subimago emerged on 27 April 2019 and the imago emerged on 30 April 2019. It is hypothesized that Cedar Bog Nature Preserve, Cedar Run, and the Mad River-remnants of streams in a prior swamp in western-central Ohio—provide a refugia for this out-of-place species.
\end{abstract}

Publication Date: December 2019

https://doi.org/10.18061/ojs.v119i2.6967

OHIO J SCI 119(2):75-78

\section{INTRODUCTION}

The spiny crawler mayfly, or to fly fishers the Dark Hendrickson, Ephemerella subvaria McDunnough, 1931, was first considered as a dark variant of Ephemerella invaria (Walker, 1853) byMcDunnough (1925). McDunnough (1931) subsequently described it as a distinct species. Allen and Edmunds (1965), in their review of the subgenus Ephemerella, provided descriptions of the nymph and adult male, and considered E. subvaria as a "boreal Eastern North American species, known from Ontario austral to Wisconsin and Pennsylvania." Their distribution map for E. subvaria covers northern Minnesota, northern Michigan, northern Pennsylvania, most of Ontario, and most of New York. More recently $E$. subvaria was reported from the southeastern United States: Kentucky, Tennessee, North Carolina, South Carolina, Virginia, and West Virginia (McCafferty et al. 2010), and as far west as Iowa and Missouri (McCafferty et al. 2003). These sources do not specify the habitats or distributions within the states. In their atlas of mayflies of Illinois, Indiana, Kentucky, Michigan, Ohio, and Wisconsin, Randolph and McCafferty (1998) record that the species is notably absent from Illinois and Ohio. Its most abundant presence is in the upper half of the Lower Peninsula of Michigan, the Upper Peninsula of Michigan, and northern Wisconsin. There are 2 outliers: the first

${ }^{1}$ Address correspondence to Donald H. Dean, Departments of Entomology, and Chemistry and Biochemistry, 484 W. 12th Ave., The Ohio State University, Columbus, OH 43214, USA. Email: dean.10@osu.edu in northern Indiana and the second in northernmost Kentucky, along the Ohio River. The database of the Ohio Environmental Protection Agency lacks records of this species from Ohio (Michael Bolton, Macroinvertebrate Biologist, Ohio EPA, pers. Commun., 2019), nor are there specimens of this taxon in The Ohio State University Museum of Biological Diversity (Luciana Musetti, Curator, University Museum of Biological Diversity, pers. commun., 2019).

Several mayflies in the genus Ephemerella were found by Hall (1985) in his study of Ephemeroptera of unglaciated Ohio, but E. subvaria was not one of them. Gaufin (1958), in his study of the effect of pollution on aquatic insects on the Mad River, identified 2 mayflies in the family Ephemerellidae: Dannella simplex (McDunnough, 1925) (reported as Ephemerella simplex) and Ephemerella which were not identified to species. Interestingly, Williams (1966) — who did an extensive study of aquatic macroinvertebrates in the Cedar Swamp (now Cedar Bog Nature Preserve; i.e., Cedar Bog) and its effluent stream, Cedar Run, for his master's research-did not report Ephemerella, although he may have missed immatures of this genus due to late-season sampling. The collection of $\boldsymbol{E}$. subvaria in Cedar Run and the Mad River is reported here for the first time in Ohio.

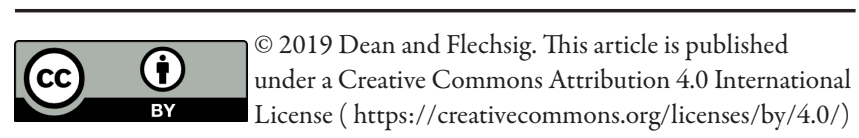




\section{METHODS AND MATERIALS}

On 26 March 2019, Ephemerella subvaria nymphs were collected from Cedar Run, 40.0345, -83.8081 (lat 4002'04.2"N, long 8348'29.2"W), approximately $1.6 \mathrm{~km}(1.0 \mathrm{mi})$ south of W. Dallas Road-and at several additional locations along the Mad River-in Champaign County, Ohio. Cedar Run, at the site of the present study, was dredged and channelized decades ago. The riparian zone of the east bank has been removed to nearly the edge of the stream for the cultivation of row crops like corn and soybeans. The west bank is characterized by American sycamore (Platanus occidentalis L.) trees and bush honeysuckle (Lonicera sp.), and with row crops beyond for a reach of approximately 3.2 $\mathrm{km}(2.0 \mathrm{mi})$. At the sampling site, the stream bed is marl covered with a thin layer of sand and fine gravel. Watercress (Nasturtium officinale W.T. Aiton) is abundant in the stream. The flow rate was not measured, but was steady, and the average gradient is $1.8 \mathrm{~m} / \mathrm{km}$ (6 feet per mile) (Williams 1966), providing a clear stream despite a heavy rain the night before one of the collections. Water temperature was $5^{\circ} \mathrm{C}\left(41^{\circ} \mathrm{F}\right)$ at the time of collections and is reported to range from -5.5 to $25.5^{\circ} \mathrm{C}\left(22\right.$ to $\left.78^{\circ} \mathrm{F}\right)$ (Frederick 1974). Sites on the Mad River, where $E$. subvaria had been collected during the current study, include above Millerstown Rd., below US 36, and above Old Troy Pike_-all part of the original 2,833 ha (7,000 acre) Cedar Swamp (Dachnowski 1910).

\section{Sampling Methods}

A standard $1 \mathrm{~m}^{2}$ kick net was used to collect nymphs in riffles from the above sites. Mature larvae were placed in a bucket of stream water oxygenated with a battery-operated bubbler. Mature larvae were reared until emersion in an aquarium outfitted with a chiller (TradeWind Chillers unit No. DI-25). Nymphs were reared in an aquarium at a constant temperature of $11^{\circ} \mathrm{C}\left(52^{\circ} \mathrm{F}\right)$, subimagoes emerged on 27 April 2019 and molted to imagoes on 30 April 2019. Specimens have been deposited at The Ohio State University Museum of Biological Diversity, the Ohio Environmental Protection Agency, and Mayfly Central at Purdue University.

\section{RESULTS AND DISCUSSION}

These collections of E. subvaria represent the first record of this mayfly species from Ohio. Nymphs were identified to genus with the keys and description of Merritt et al. (2008) and to species with the description and keys of Allen and Edmunds (1965). The identification was confirmed by Luke Jacobus (Indiana University-Purdue University Columbus, Columbus, Indiana), who recently revised Ephemerellidae (see Jacobus and McCafferty 2008). The species has also been collected at several locations on the Mad River, near Cedar Run and Cedar Bog. The key attributes of the nymphs are quite distinct (Figs. 1 and 2): the tibiae and tarsi are clearly marked with dark bands; the abdomen has gills on segments 4 to 7; and a white band across the middle of the abdominal segments 5 to 7 , on an otherwise dark background, a feature of the species. Ephemerella excrucians, a complex of species (McCafferty et al. 2017) may have, in somevariants, light-mottled bands across tergi 5 to 6 (not 7), but lacks turgal-paired spines or turbercles. The dorsal segments (terga) 2 to 8 on E. excrucians have paired spines or tubercles that are distinct and raised but not arching.

The occurrence of $E$. subvaria in Champaign County, western-central Ohio, represents a new range extension for the species. This species, in the upper Midwest United States, is typically found

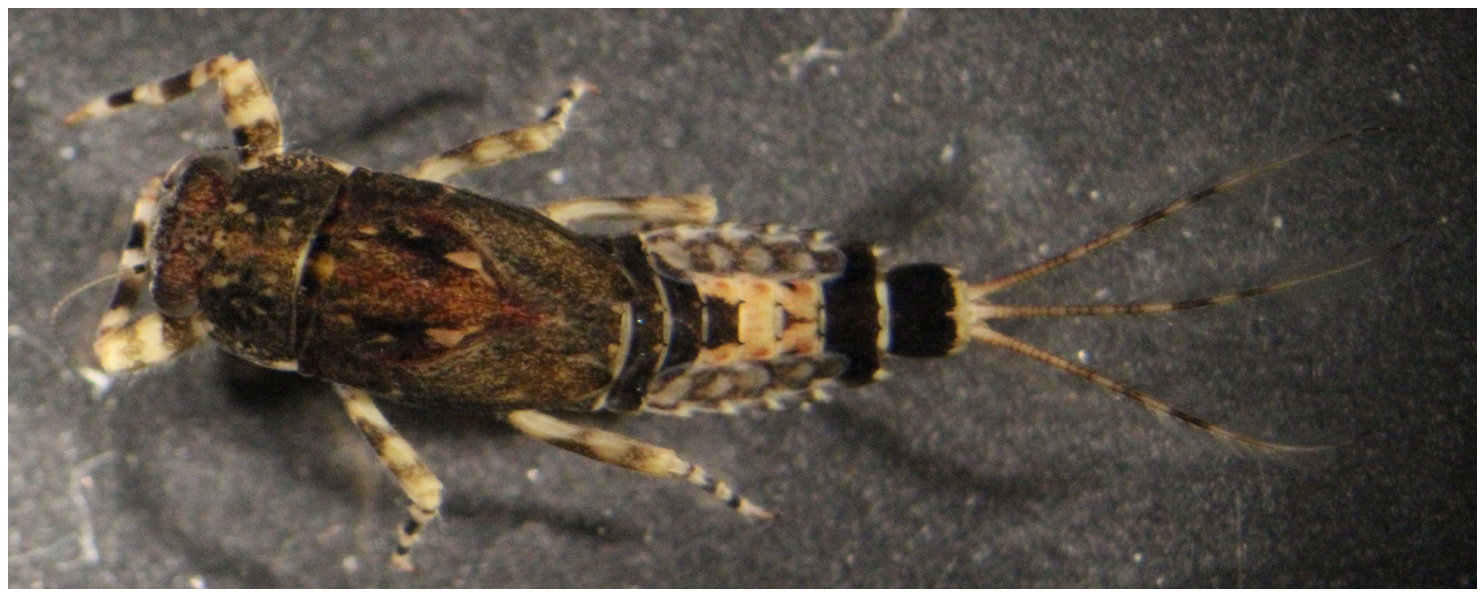

FIGURE 1. Ephemerella subvaria McDunnough nymph, dorsal 


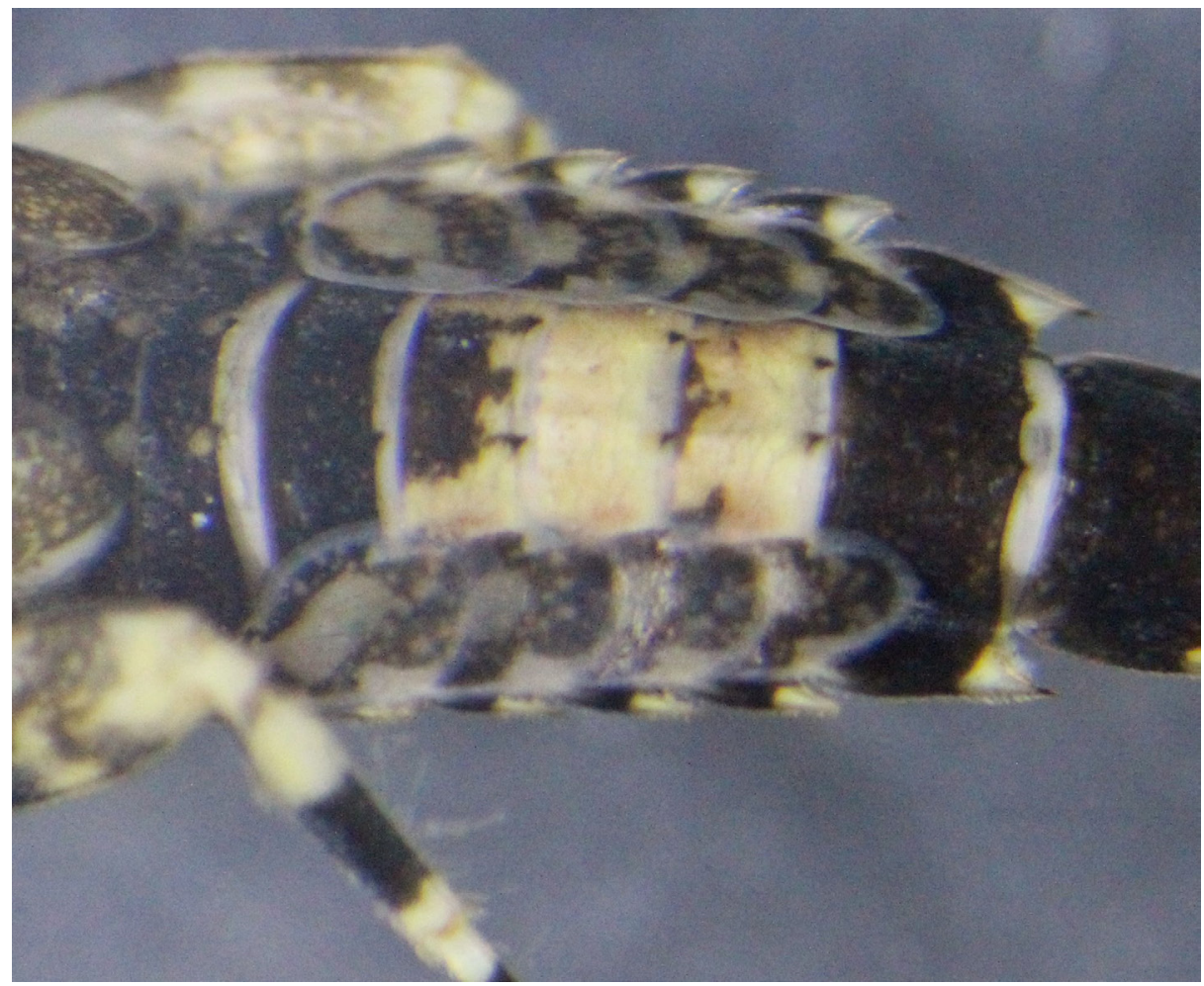

FIGURE 2. Tergae, indicating paired raised spines on segments 2 to 9

much further north, especially in the upper half of the Lower Peninsula of Michigan, the Upper Peninsula of Michigan, and northern Wisconsin (Fig. 3) (Randolph and McCafferty 1998).

The collection site on Cedar Run is approximately $2.9 \mathrm{~km}(1.8 \mathrm{mi})$ southwest of the Cedar Bog; the latter is a possible source for the species' existence in Ohio. Cedar Bog, a 180.5 ha (446 acre) alkaline fen, is a remnant of a previous swamp of over 2,833 ha (7,000 acres) before draining and conversion to agricultural fields (Dachnowski 1910). This fen has at least 6 species of plants that typically occur in the bogs of northern Michigan (Frederick 1974).

There are several other species of Ephemerellidae known from the Mad River watershed: Ephemerella needhami McDunnough, 1925; Eurylophella sp. Tiensuu, 1935; Teloganopsis deficiens (Morgan, 1911); and Dannella simplex (McDunnough, 1925) (OEPA 2005).

Waters and Crawford (1973) reported the life history of E. subvaria in a small stream in central Minnesota. There, the adults emerged in late spring and no nymphs remained in the stream after the first of July. In the current study, no nymphs were collected in Cedar Run during the last sampling period on 22 April 2019. The Ohio strain, reared in an aquarium kept at a constant temperature of $11^{\circ} \mathrm{C}\left(52^{\circ} \mathrm{F}\right)$, emerged as subimago (dun) on 27 April 2019 and as imago (spinner) 30 April 2019.
The remaining questions are why E. subvaria has not been previously reported in the scientific literature from Ohio and whether Cedar Bog is, indeed, the focal point of their presence in western-central Ohio. One reason they have not been previously reported may be that most entomologists, including the extensive surveillance by Ohio EPA, do not monitor early in the season; however, this species has emerged, mated, laid its eggs, and is absent from the rivers as a detectable macroinvertebrate by the middle of spring. Further study is required to learn if Cedar Bog is the nexus of E. subvaria in Ohio.

If, indeed, E. subvaria is restricted to a portion of the Mad River and Cedar Run river system, then conservation efforts may be needed to keep it extant in the state. The heavy siltation (due to farm run-off) and the nutrient spike (due to excessive use of fertilizers) currently observed along the Mad River have a direct negative impact on aquatic macroinvertebrates. Clearly E. subvaria and other aquatic insects are threatened by the declining habitat in this watershed.

\section{ACKNOWLEDGEMENTS}

Thanks are due to John Lorenz for help with collecting the specimens, and Luke Jacobus (Indiana University-Purdue University Columbus) and Mike Bolton (Ohio EPA) for examining the specimens and confirming their identification. 


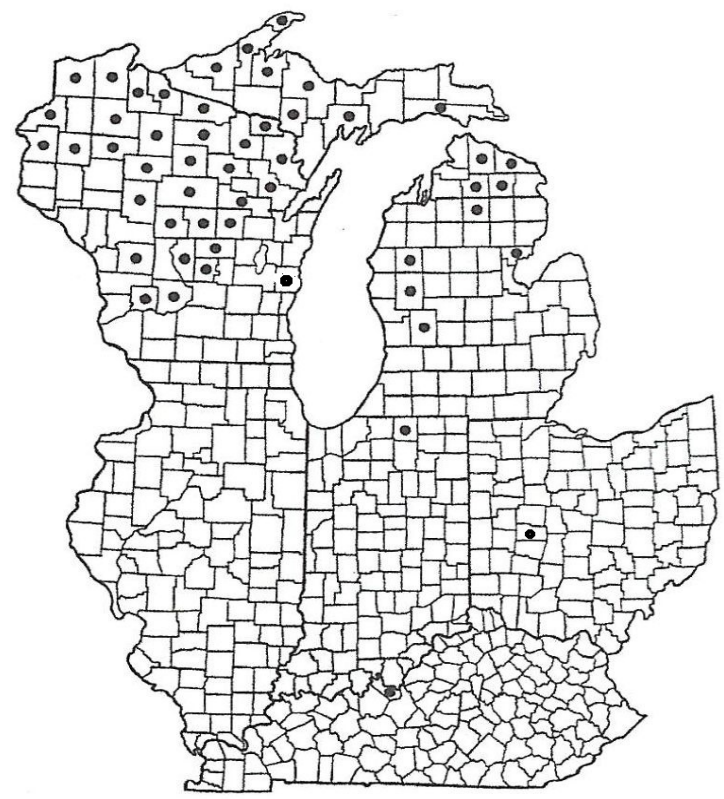

FIGURE 3. Distribution of Ephemerella subvaria in the Midwest United States (from Randolph and McCafferty 1998; used with permission). The original figure was modified as follows: A dot was added in Cheboygan County, Wisconsin (Klubertanz 2016). A dot was added in Champaign County, Ohio (current study).

\section{LITERATURE CITED}

Allen RK, Edmunds GF. 1965. A revision of the genus Ephemerella (Ephemeroptera, Ephemerellidae) VIII: the subgenus Ephemerella in North America. In: Misc Pub Entomol Soc Am. 4(6):244-282. College Park (MD): Entomological Society of America. OCLC No.: ocm00042902

Dachnowski A. 1910. A cedar bog in central Ohio. Ohio Nat. 11(1):193-199.

https://doi.org/10.1086/330683 and https://kb.osu.edu/bitstream/handle/1811/1689/1/V11N01_193.pdf

Frederick CM. 1974. A natural history study of the vascular flora of Cedar Bog, Champaign County, Ohio. Ohio J Sci. 74(2):65-116. http://hdl.handle.net/1811/22204

Gaufin AR. 1958. The effects of pollution on a midwestern stream. Ohio J Sci. 58(4):197-208. http://hdl.handle.net/1811/4544

Hall RL. 1985. New collection records of Ohio mayflies (Ephemeroptera). Entomol News. 96(4):171-174. http://direct.biostor.org/reference/77039

Jacobus LM, McCafferty WP. 2008. Revision of Ephemerellidae genera (Ephemeroptera).TAm Entomol Soc. 134(1):185-274. https://doi.org/10.3157/0002-8320(2008)134[185:roege]2.0.co;2

Klubertanz TH. 2016. Mayfly larvae of Wisconsin. Madison (WI): University of Wisconsin-Extension, Cooperative Extension. 291 p. Series G4074. ISBN13: 978-0-9801401-6-3.

McCafferty WP, Jacobus LM, Provonsha AV, Wiersema NA. 2017. Ephemeroptera. In: Morse JC, McCafferty WP, Stark BP, Jacobus LM, editors. Larvae of the southeastern USA mayfly, stonefly, and caddisfly species (Ephemeroptera, Plecoptera, and Trichoptera). Biota of South Carolina, Vol. 9. Technical Bulletin 1109. Clemson (SC): Clemson Public Service and Agriculture, Clemson Univ. p. 15-160.

McCafferty WP, Lenat DR, Jacobus LM, Meyer MD. 2010. The mayflies (Ephemeroptera) of the southeastern United States. T Am Entomol Soc. 136(3-4):221-233. https://doi.org/10.3157/061.136.0303
McCafferty WP, Hubbard T, Klubertanz TH, Randolph RP, Birmingham M. 2003. Mayflies (Ephemeroptera) of the Great Plains. II: Iowa. T Am Entomol Soc. 129(1):77-105. https://www.jstor.org/stable/25078798

McDunnough J. 1925. The Ephemeroptera of Covey Hill, Quebec: T Roy Soc Can. 19(series 3):207-224.

https://hdl.handle.net/2027/uc1.b3065304

McDunnough J. 1931. New species of North American Ephemeroptera. Can Entomol. 63(4):82-93. https://doi.org/10.4039/ent6382-4

Merritt RW, Cummins KW, Berg MB, editors. 2008. An introduction to the aquatic insects of North America. 4th ed. Dubuque (IA): Kendall Hunt Publishing Company. 1158 p. ISBN13: 978-0757563218.

[OEPA] Ohio Environmental Protection Agency. 2005. Biological and water quality study of the Mad River Basin, 2003: Logan, Champaign, Clark, Miami, Green, and Montgomery Counties, Ohio. Columbus (OH): State of Ohio Environmental Protection Agency, Division of Surface Water. OEPA Technical Report ESA/2005-5-5. 216 p. Available from: Division of Surface Water, P.O. Box 1049, Columbus, Ohio, 43216-1049. With separate appendices.

Randolph RP, McCafferty WP. 1998. Diversity and distribution of the mayflies (Ephemeroptera) of Illinois, Indiana, Kentucky, Michigan, Ohio, and Wisconsin. Ohio Biol Surv Bull, New Series. 13(1). Columbus (OH): Ohio Biological Survey. 188 p. ISBN13: 978-0867271317. http://www.ohiobiologicalsurvey.org/books_posters/

Waters TF, Crawford GW. 1973. Annual production of a stream mayfly population: a comparison of methods. Limnol Oceanogr. 18(2):286-296.

https://doi.org/10.4319/lo.1973.18.2.0286

Williams JL. 1966. A biological survey of Cedar Run, Champaign County, Ohio, with special emphasis on aquatic insects [master's thesis]. [Columbus $(\mathrm{OH})$ ]: The Ohio State University. $121 \mathrm{p}$. 